\title{
SISTEM INFORMASI PENJUALAN DAN PERSEDIAAN BARANG PADA CV. KURNIA DJASA BERSAMA
}

\author{
Muhammad Alfin Aldianto', Wahyu Nur Cholifah², Aulia Ar Rakhman Awaludin ${ }^{3}$ \\ ${ }^{1,2,3}$ Universitas Indraprasta PGRI \\ Jl. Raya Tengah No. 80, Kel. Gedong, Kec. Pasar Rebo, Jakarta Timur 13760, Jakarta \\ $\underline{1 \text { alvinaldianto@gmail.com, }}{ }^{2}$ wncholifah.web@gmail.com, ${ }^{3}$ aulia awaludin@yahoo.co.id
}

\begin{abstract}
ABSTRAK
CV. Kurnia Djasa Bersama merupakan perusahaan yang bergerak di bidang perdagangan jual-beli suku cadang kendaraan alat berat seperti Excavator, Bulldozer, dan Wales Stump. Permasalahan yang ada pada perusahaan antara lain belum adanya aplikasi, pencatatan transaksi penjualan dan transaksi pembelian masih manual, proses pengecekan persediaan barang pada gudang masih dilakukan masih satu per satu serta dibutuhkan waktu yang lama dalam proses pembuatan laporan. Tujuan dari penelitian ini yaitu merancang sebuah sistem informasi berbasis java yang dapat memudahkan karyawan dalam mengelola data barang, data transaksi penjualan, data transaksi pembelian, dan pembuatan laporan sehingga semua pencatatan lebih terkomputerisasi, lebih cepat, dan lebih akurat. Metode penelitian yang dilakukan adalah metode penelitian kualitatif yang dimana pada metode ini peneliti lebih menekankan kepada makna sehingga peneliti dapat memahami fenomena-fenomena yang terjadi pada perusahaan. Hasil dari penelitian ini adalah terbentuknya sistem informasi penjualan dan persediaan barang berbasis java yang dapat mengolah dan menyimpan data di database serta dapat memberikan informasi yang cepat dan akurat.
\end{abstract}

Kata Kunci: Sistem informasi, Penjualan, Persediaan, MySQL, Java

\section{ABSTRACT}

CV. Kurnia Djasa Bersama is a company engaged in the trading of spare parts for heavy equipment vehicles such as Excavators, Bulldozers, and Wales Stumps. The problems that exist in the company include the absence of an application, the recording of sales transactions and purchase transactions is still manual, the process of checking inventory in the warehouse is still done one by one and it takes a long time in the process of making reports. The purpose of this research is to design a java-based information system that can facilitate employees in managing goods data, sales transaction data, purchase transaction data, and making reports so that all records are more computerized, faster, and more accurate. The research method used is a qualitative research method where in this method the researcher emphasizes more on meaning so that researchers can understand the phenomena that occur in the company. The result of this research is the formation of a Java-based sales and inventory information system that can process and store data in a database and can provide fast and accurate information.

Key Word: Information system, Sales, Inventory, MySQL, Java

\section{PENDAHULUAN}

Perkembangan teknologi sistem informasi di Indonesia saat ini berkembang sangat pesat hal ini dapat dilihat dari bermunculanya berbagai macam solusi teknologi informasi yang ditawarkan oleh pelaku bisnis untuk memperoleh keuntungan. Di Indonesia sendiri penggunaan teknologi sistem informasi masih didominasi oleh pihak swasta hal ini dapat dimaklumi karena dengan adanya kemajuan teknologi informasi mampu meningkatkan daya saing. Penggunaan sistem informasi dilakukan karena memiliki beberapa kelebihan diantaranya untuk meningkatkan efektifitas, produktifitas, akses informasi yang sangat mudah dan mudah untuk dikembangkan.
CV. Kurnia Djasa Bersama adalah badan usaha yang bergerak di bidang penjualan mesin-mesin, suku cadang, dan perlengkapan alat berat seperti seals O'ring, Fitting Elbow, dan Hydraulic Seals yang digunakan pada kendaraan alat berat, contohnya Excavator, Bulldozer, dan Wales Stump. Adapun beberapa kelemahan pada proses pendataan penjualan pada sistem yang berjalan yang masih manual dengan menggunakan Ms.Excel sebagai pencatatan data penjualan dan persediaan barang, dan membutuhkan waktu yang lama dalam pembuatan laporan. berdasarkan permasalah tersebut penulis melakukan penelitian untuk mengembangkan 
aplikasi pengolahan data penjualan dan persediaan pada CV. Kurnia Djasa Bersama.

Tujuan dari penelitian ini adalah merancang suatu sistem penginputan data transaksi menjadi terkomputerisasi dan otomatis. Perancangan sebuah sistem informasi penjualan dan persediaan barang pada suku cadang alat berat yang akan memudahkan karyawan dalam melakukan pencatatan data ataupun perubahan data ketika transaksi terjadi.

Sistem informasi adalah suatu sistem didalam suatu organisasi yang mempertemukan kebutuhan pengolahan transaksi harian yang mendukung fungsi operasi organisasi yang bersifat manajerial dengan kegiatan strategi dari suatu organisasi untuk dapat menyediakan laporan-laporan yang diperlukan oleh pihak luar tertentu (Sutabri, 2012). Dan Sistem Informasi adalah Suatu sistem didalam suatu organisasi yang mempertemukan kebutuhan pengelolaan transaksi harian, mendukung operasi, bersifat majerial, dan kegiatan stategi dari suatu organisasi dan menyediakan piak luar tertentu dengan laporan-laporan yang dibutuhkan (Hutahaean, 2015).

Penjualan merupakan kegiatan yang dilakukan oleh penjual dalam menjual barang dan jasa dengan impian akan mendapatkan laba dari terdapatnya transaksi-transaksi tersebut dan penjualan bisa diartikan sebagai mengalihkan atau memindahkan hak kepemilikan atas barang atau jasa dari pihak penjual ke pembeli (Mulyadi, 2016). Persediaan adalah Persediaan (Inventory) adalah stok dari suatu item atau sumber daya yang di gunakan dalam suatu organisasi perusahaan (Assauri, 2016). Alat berat adalah Alat berat adalah mesin berukuran besar yang didesain untuk melaksanakan fungsi konstruksi seperti pekerjaan tanah dan memindahkan bahan bangunan. Alat berat pada umumnya terdiri atas lima komponen, yaitu implemen, alat traksi, struktur, sumber tenaga dan transmisinya (power train), serta sistem kendali (Achmad, Mudianto, \& Wiranto, 2016).

Dalam pembuatan sistem informasi penjualan dan persediaan barang dilakukan menggunakan bahasa pemrograman Java dengan menggunakan aplikasi Netbeans, dan menggunakan database MySQL. Bahasa pemrograman java yaitu dimana sekumpulan teknologi untuk membuat dan menjalankan perangkat lunak pada komputer stand alone ataupun pada lingkungan jaringan (Warno, 2012), dan pengertian netbeans menurut Kurniawan mengemukakan bahwa "Netbeans merupakan sebuah software yang digunakan untuk membuat sebuah aplikasi berbasis java. Software ini digunakan sebagai media untuk menjalankan program dan software ini mempermudah kita untuk melihat kesalahan dari program tersebut" (Kuryanti, 2014).

Manfaat yang diharapkan oleh penulis adalah dapat meningkatkan layanan bagi pelanggan, serta mempercepat proses transaksi yang terjadi maupun saat pembuatan laporan.

\section{METODE PENELITIAN}

Metode yang digunakan oleh penulis dalam langkah-langkah pengembangan sistem adalah metode waterfall yaitu "suatu proses pengembangan perangkat lunak berurutan, di mana kemajuan dipandang sebagai terus mengalir ke bawah (seperti air terjun) melewati fase-fase perencanaan, pemodelan, implementasi (konstruksi), dan pengujian" (Tristianto, 2018).

Penelitian dilakukan di CV.Kurnia Djasa Bersama yang beralamat di Jl. Hayam Wuruk No.127, Jakarta Barat 11180. Dalam waktu 4 bulan penulis melakukan pengumpulan data dengan menggunakan metode penelitian kualitatif, metode kualitatif adalah metode penelitian yang berlandaskan pada filsafat, yang digunakan untuk meneliti pada kondisi ilmiah (eksperimen) dimana peneliti sebagai instrumen, teknik pengumpulan data dan di analisis yang bersifat kualitatif lebih menekan pada makna (Sugiyono, 2018)

Metode pengumpulan data yang dilakukan oleh penulis, diantaranya:

Studi kepustaan yaitu metode pengumpulan data dengan cara mempelajari beberapa literature baik dari buku, jurnal serta media elektronik yang berhubungan dengan materi Observasi yaitu metode mendapatkan data dengan melakukan pengamatan langsung untuk memperoleh data dan informasi yang dibutuhkan et al. 
Wawancara yaitu teknik pengumpulan data yang dilakukan melalui tatap muka dan tanya jawab langsung kepada karyawan untuk memperoleh data dan informasi yang dibutuhkan. Jenis wawancara yang digunakan adalah wawancara tidak terstruktur yang diharapkan mendapatkan banyak informasi yang lebih mendalam atau hal baru sebagai penunjang pembahasan dan hasil penelitian.

Dalam pengembangan sistem peneliti melakukan langkah-langkah pengembangan sistem dengan menggunakan metode waterfall sebagai berikut:

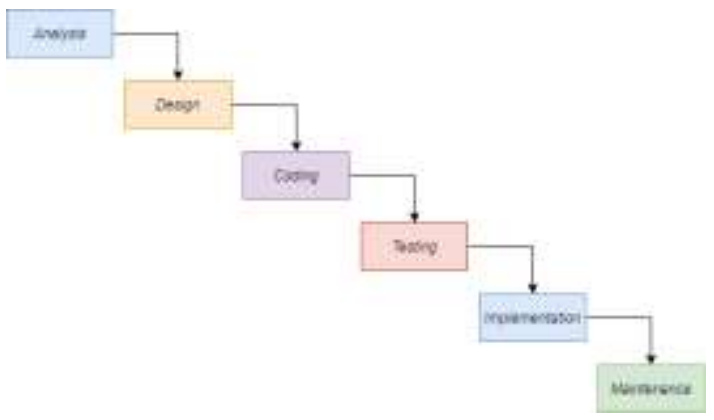

Gambar 1. Langkah-langkah pengembangan sistem

\section{HASIL DAN PEMBAHASAN}

Berdasarkan analisis penulis dapat mengusulkan beberapa masalah yang ada pada CV. Kurnia Djasa Bersama, yaitu:

1. Proses pendataan penjualan dan pembelian masih menggunakan Ms.Excel sebagai media penyimpanan datanya.

2. Terjadi dua kali pencatatan pada proses penjualan, yaitu pada pembuatan invoice dan pada pencatatan di MS.Excel.

3. Proses pengecekan barang pada suku cadang alat berat masih satu per satu

4. Dibutuhkan waktu yang lama dalam proses pembuatan laporan.

Untuk mengatasi masalah yang terjadi pada CV. Kurnia Djasa Bersama penulis mengusulkan alternative penyelesaian masalah dengan merancang suatu Sistem Penjualan dan Persediaan barang. Sistem ini merupakan aplikasi yang diharapkan dapat memberikan solusi dari permasalahan yang sedang dihadapi. Adapun solusi dari Sistem Penjualan dan Pesediaan Barang yang akan dirancang tersebut sebagai berikut :

1. Semua data transaksi penjualan dan persediaan barang disimpan dalam sebuah database untuk mengelola data lebih effisien.

2. Saat terjadinya suatu transaksi, maka akan diiringi dengan perubahan sesuai dengan transaksi yang berjalan. Jika terjadi penjualan, persediaan barang akan berkurang, dan saat melakukan pembelian barang, persediaan barang akan bertambah.

3. Proses pengecekan barang cukup dilihat melalui aplikasi tanpa harus melakukan pengecekan langsung ke gudang.

4. Sistem yang dirancang akan mempermudah staff admin dalam melakukan pengolahan data dan pencarian data.

5. Sistem dilengkapi penyaringan laporan, dan telah di kelompokan berdasarkan waktu tertentu dan dapat mempercepat proses pembuatan laporan.

Pada sistem yang diusulkan penulis menggunakan UML untuk mendefinisikan sebuah sistem yang akan dirancang, Menurut sukamto dan salahuddin UML adalah "salah satu standar bahasa yang banyak digunakan didunia industri untuk mendefinisikan requirement, membuat analisis dan desain, serta menggambarkan arsitektur dalam pemrograman berorientasikan objek". Berikut adalah use case diagram:

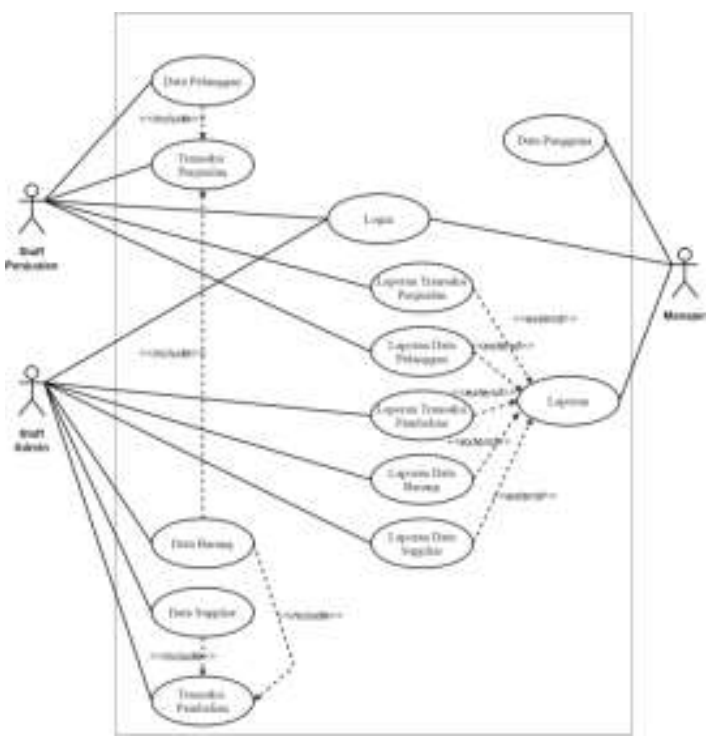

Gambar 2. Use case diagram

Menurut Sukamto dan Salahuddin "Use case atau diagram use case merupakan pemodelan untuk melakukan kelakuan (behavior) sistem informasi yang akan dibuat. Use case 
mendeskripsikan sebuah interaksi antara satu atau lebih aktor dengan sistem informasi yang akan dibuat". (Sukamto \& Salahuddin, 2014)

Berikut adalah tampilan layar dari sistem yang telah dibuat.

\section{Tampilan Login}

Tampilan login adalah tampilan awal saat aplikasi pertama kali dibuka, pengguna dapat memasukan username dan password yang telah didaftarkan oleh pihak manajer, dan mengklik tombol "Masuk" dan akan diarahkan ke tampilan menu utama, tampilan login berguna untuk mencegah orang yang tidak bertanggung jawab menggunakan aplikasi ini, selain itu tampilan login ini juga berguna untuk membatasi hak akses dari para pengguna aplikasi ini.

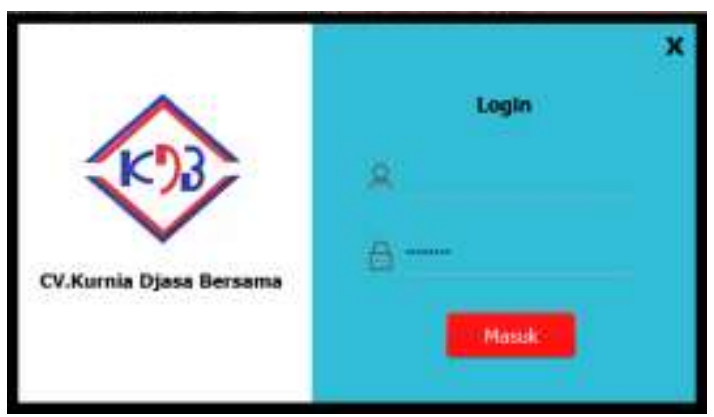

Gambar 3. Tampilan login

\section{Tampilan Menu Utama}

Setelah berhasil login pengguna akan diarahkan ke tampilan menu utama. Tampilan menu utama ini berfungsi sebagai penghubung antar form satu dengan form yang lain.

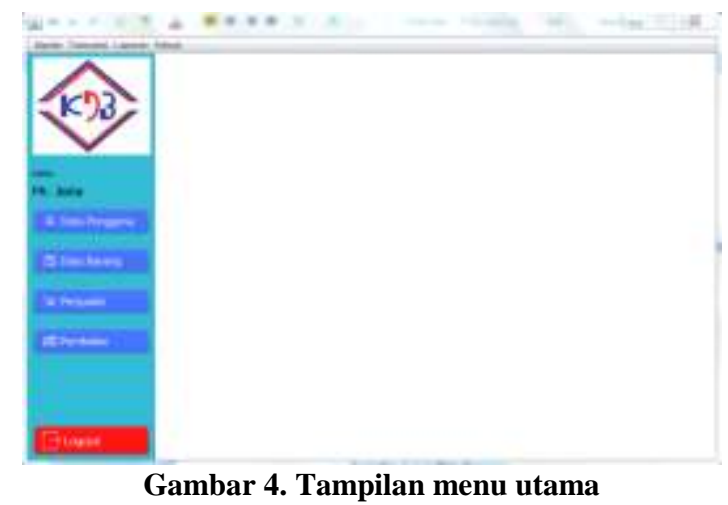

\section{Tampilan Data Barang}

Tampilan data barang berfungsi sebagai penginputan data barang untuk melakukan penambahan barang baru, perubahan data barang ataupun menghapus suatu barang dari data barang.

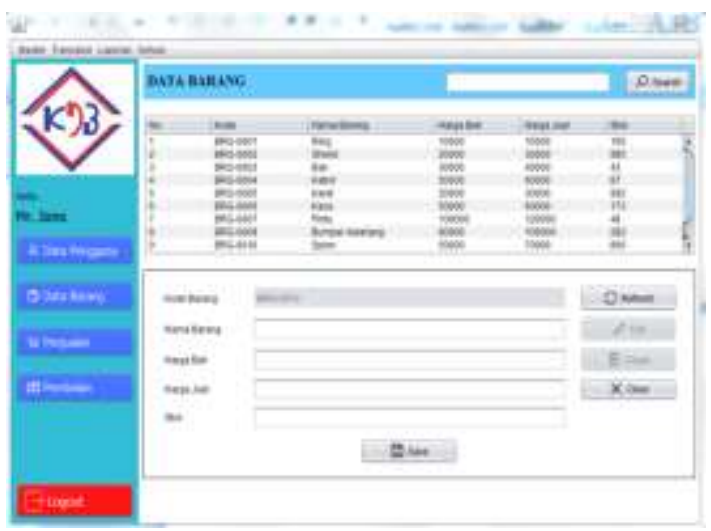

Gambar 5. Tampilan data barang

\section{Tampilan Transaksi Penjualan}

Tampilan transaksi penjualan berfungsi sebagai penginputan data transaksi ketika transaksi penjualan terjadi, yaitu dengan memasukan nama pelanggan dan memasukan data-data barang yang akan di jual, setelah itu mengklik tombol "save", maka invoice penjualan akan tercetak dan menyimpan data transaksi ke database.

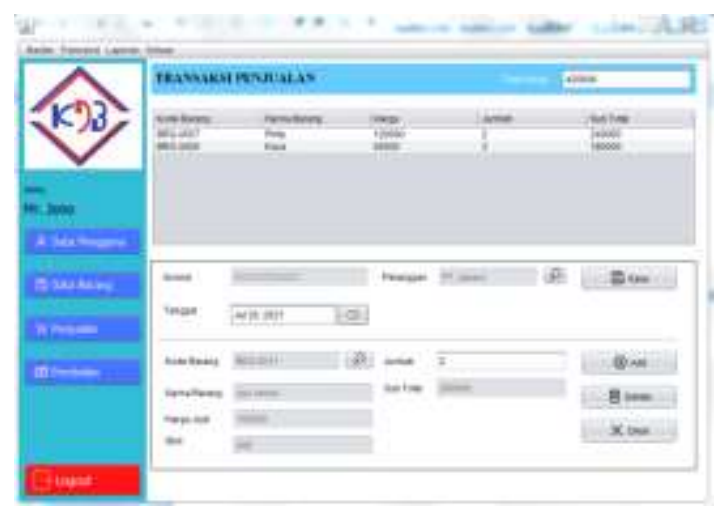

Gambar 6. Tampilan transaksi penjualan

\section{Tampilan Transaksi Pembelian}

Tampilan transaksi pembelian berfungsi sebagai penginputan data transaksi ketika terjadi transksi pembelian terhadap supplier, sama seperti transaksi penjualan, pengguna dapat memasukan invoice dan nama supplier, setelah itu pengguna memasukan data-data barang yang telah di beli pada transaksi tersebut. 


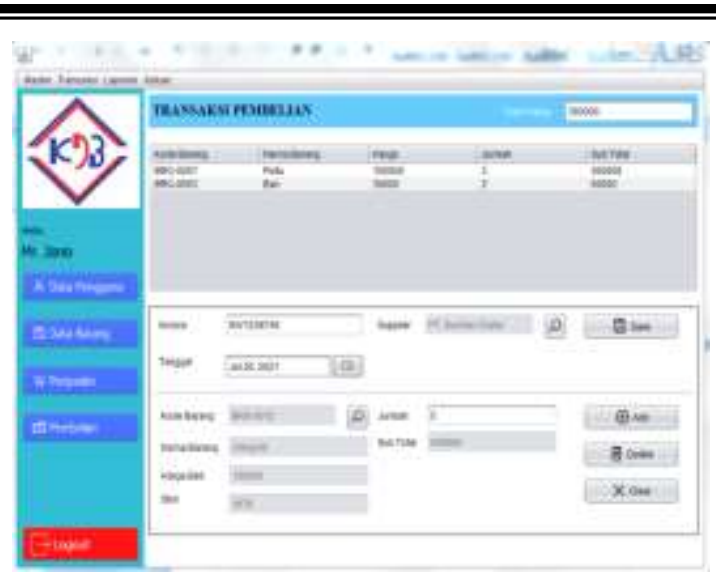

Gambar 7. Tampilan transaksi pembelian

\section{Tampilan Laporan Penjualan}

Laporan penjualan berfungsi sebagai laporan penjualan yang telah terjadi pada periode yang ditentukan, laporan penjualan dapat di cetak oleh staff penjualan dan juga manajer.

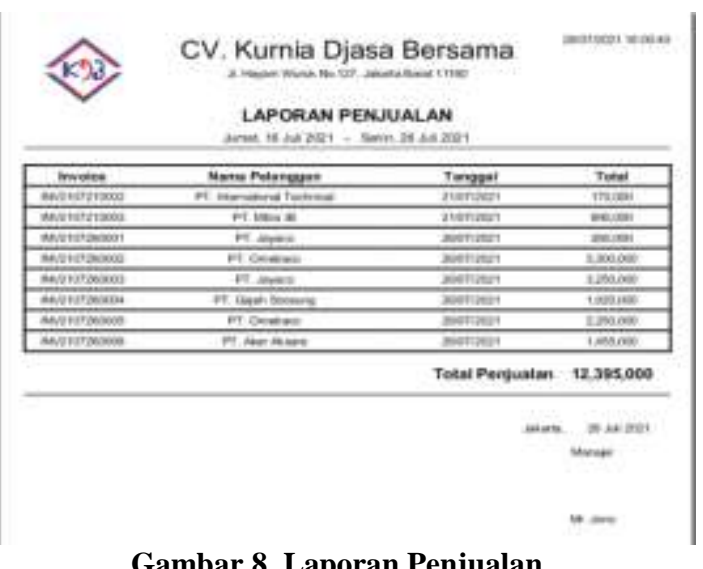

Gambar 8. Laporan Penjualan

\section{Tampilan Laporan Pembelian}

Laporan pembelian berfungsi sebagai laporan pembelian yang telah terjadi pada periode yang ditentukan, laporan pembelian dapat di cetak oleh staff admin dan juga manajer.

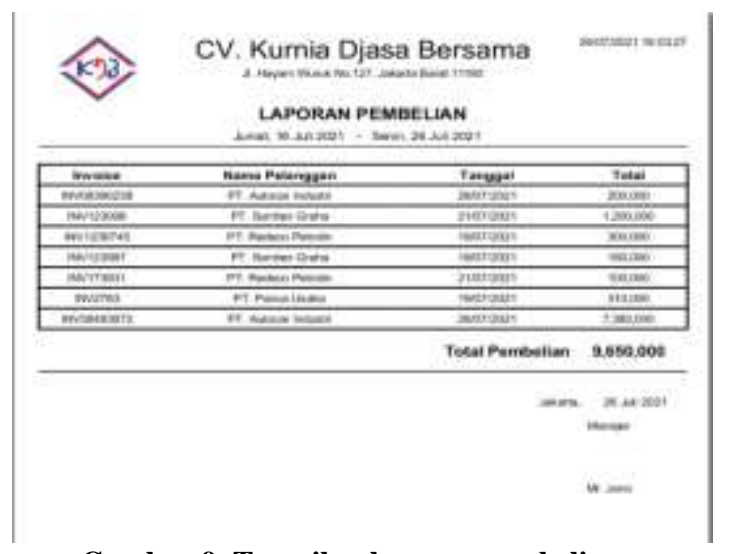

Gambar 9. Tampilan laporan pembelian

\section{Laporan Data Barang}

Laporan data barang berfungsi sebagai laporan untuk mengetahui persediaan barang pada data yang telah di masukan kedalam data barang. Sehingga pihak perusahaan dapat mengetahui barang yang harus di beli agar tidak kehabisan persediaan barang.

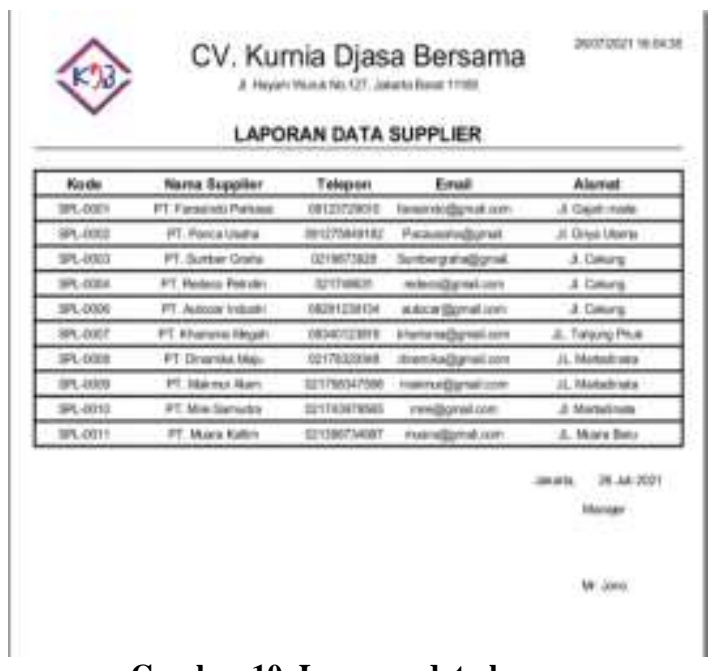

Gambar 10. Laporan data barang

\section{SIMPULAN DAN SARAN}

Dari hasil pembahasan yang telah diuraikan sebelumnya, maka dapat disimpulkan bahwa: Sistem informasi data penjualan dan persediaan barang pada CV. Kurnia Djasa Bersama dirancang menggunakan bahasa pemrograman Java yang dibantu dengan aplikasi Netbeans, dan juga menggunakan database MySQL.

Dengan adanya Sistem informasi data penjualan dan persediaan barang pada $\mathrm{CV}$. Kurnia Djasa Bersama dapat mempermudah karyawan dalam melakukan pendataan penjualan dan persediaan barang. Sistem informasi data penjualan dan persediaan barang pada CV. Kurnia Djasa Bersama juga dapat mempercepat karyawan dalam pembuatan laporan maupun invoice, sehingga dapat meningkatkan pelayanan kepada pelanggan.

Adapun saran yang di usulkan penulis kepada CV. Kurnia Djasa Bersama, antara lain kedepannya aplikasi ini dapat dikembangkan berbasis website, sehingga dapat di akses dimanapun. Sistem informasi ini dibutuhkan backup data dan maintenance secara berskala. 


\section{DAFTAR PUSTAKA}

Achmad, H. S., Mudianto, A., \& Wiranto, P. (2016). Kajian Penggunaan Alat-Alat Berat Pada Proyek Pembangunan Jalan Raya Ditinjau Dari Aspek Teknis Dan Ekonomi. Jurnal Online Mahasiswa.

Assauri, S. (2016). Manajemen Operasi Produksi Pencapaian Sasaran Organisasi Berkesinambungan. Jakarta: PT. Raja Grafindo Persada.

Hutahaean, J. (2015). Konsep Sistem Informasi. Yogyakarta: Deepublish.

Kuryanti, S. J. (2014). Perancangan Sistem Informasi Akademik Sekolah Berbasis Web Dengan Java. Jurnal Khatulistiwa Informatika, 2(1).

Mulyadi. (2016). Sistem Akuntasi. Jakarta: Salemba Empat.

Sugiyono. (2018). Prof. Dr. Sugiyono. 2018. Metode Penelitian Kuantitatif, Kualitatif, dan $R \& D$. Bandung: Alfabeta.

Sukamto, R. A., \& Salahuddin, M. (2014). Rekayasa Peraangkat Lunak Terstruktur dan Berorientasi Objek. Bandung: Informatika.

Sutabri, M. T. (2012). Analisa Sistem Informasi. Yogyakarta: Andi.

Tristianto, C. (2018). Penggunaan Metode Waterfall Untuk Pengembangan Sistem Monitoring Dan Evaluasi Pembangunan Pedesaan. Jurnal Teknologi Informasi ESIT.

Warno. (2012). Pembelajaran Pemrograman Bahasa Java Dan Arti Keyword. Jurnal Komputer, 8(1). 